\title{
A indeterminada questão da raça
}

\section{The indeterminate question of race}

\author{
Kaori Kodama \\ Professora e pesquisadora da Casa de Oswaldo Cruz (COC)/Fiocruz. \\ kaori@coc.fiocruz.br
}

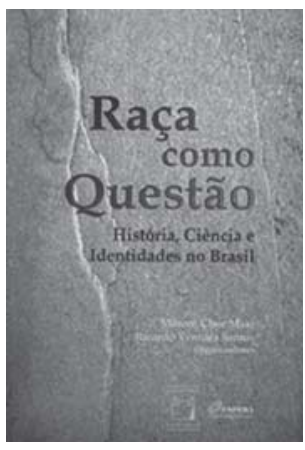

MAIO, Marcos Chor; SANTOS, Ricardo Ventura (Org.). Raça como questão: história, ciência, identidades no Brasil. Rio de Janeiro: Editora Fiocruz, 2010 $314 p$.
$\mathrm{T}$ ratar da questão raça é tarefa que se mostra sempre espinhosa. Ponto de partida de inúmeras polêmicas científicas ou políticas e de incontáveis análises, a discussão do tema parece ainda estar refratada em seus significados e interesses em âmbitos diferentes, seja no interior dos campos de conhecimento científico, seja no seio da própria sociedade criadora e reificadora das 'relações raciais'.

A obra ora apresentada, Raça como questão, é coletânea valiosa para todos aqueles que se interessam pelos temas ciência, sociedade e nação, e suas mútuas imbricações referentes à discussão sobre raça. Se os 11 capítulos que compõem o livro não foram concebidos como um conjunto, posto que se trata de textos abrigados originalmente em outras publicações, é bastante notável a estrutura bem organizada que formam no todo. Nesse novo trabalho, Marcos Chor Maio e Ricardo Ventura dos Santos exploram, sob outros olhares, temáticas que foram pauta de discussão em livro anterior, Raça, ciência e sociedade, que ainda hoje serve de referência para historiadores,

sociólogos e afins. Tal como nessa coletânea, de 1996, a questão da raça é exposta na de 2010 em encadeamento de capítulos que tem por fios condutores o pensamento social brasileiro, a medicina, a biologia, a antropologia e os movimentos sociais.

As semelhanças com a primeira organização dos autores revelam-se ainda por algumas premissas de abordagem que retomam 'raça' nas diferentes interfaces discursivas, em particular, as da ciência, dos grupos sociais e das políticas, o que, em seu conjunto, acaba por desconstruir o próprio conceito de raça. Também ao modo do primeiro livro, o debate racial é transposto no tempo, em recuo que visa revelar aspectos dos debates científicos sobre o tema como construções que se fazem de forma pertinente às enunciações sobre nação no Brasil. No livro o ponto de partida é o intervalo de tempo que se estende de finais da monarquia ao início do período republicano. Com efeito, é esse recorte temporal que a análise de Jair de Souza Ramos e Marcos Chor Maio enfoca de forma mais direta no primeiro capítulo. Os autores abordam o modo como intelectuais brasileiros de fins do século XIX e início do XX, entre eles, Sílvio Romero, Nina Rodrigues e Euclides da Cunha, lidaram com o legado da escravidão e um arcabouço teórico condenatório das raças mestiças que impediria a formulação de imagem positiva para a nação brasileira. Esses intelectuais, observam os autores, foram também produtores de discursos que, embora levando a 
consequências às vezes opostas, matizaram as teorias racialistas em voga com a necessidade de pensar a viabilidade da formação do 'povo' ou da nação brasileira.

Seguindo esse argumento da busca original, por parte de intelectuais e médicos, da questão do determinismo racial, o capítulo seguinte contesta a ideia de que haveria viés claramente racial nas políticas de saúde brasileiras no final do Império e durante a Primeira República. Se tais políticas elegeram mormente o combate à febre amarela, que se acreditava devorar os imigrantes europeus, poupando africanos e seus descendentes, o que revelaria como intenção política o racismo, como lembrou Sidney Chalhoub em Cidade febril (1993), a perspectiva assumida no capítulo é de que, não obstante polifônico, o campo médico teria dado mais ênfase à influência das condições climáticas e de dieta na conformação dos indivíduos do que aos princípios mais essencialistas, que conduziram ao racialismo. Essa diretriz reforça, em certa medida, a busca de os próprios médicos e higienistas se tornarem protagonistas das políticas públicas, e estaria ainda presente quando a raça passava a ser conteúdo quase incontornável das teorias sociais e médicas sobre o Brasil, criadas a partir do último quartel do século XIX. O capítulo conclui que as escolhas das políticas em saúde pública, não obstante o forte peso científico das teorias raciais de finais daquele século, não se apartaram de uma tradição médico-higienista anteriormente estabelecida, que frisou a preponderância dos aspectos socioambientais como determinantes da conformação dos 'males do Brasil'.

Perseguindo ainda o problema dos determinismos raciais e as formas ambíguas com que ele se inscreveu nas ciências praticadas no Brasil a partir da década de 1870, os dois capítulos seguintes focalizam o Museu Nacional enquanto importante lócus das produções antropológicas até a década de 1930. No capítulo de Ricardo Ventura dos Santos, são analisadas as 'versões' da antropologia física de Batista de Lacerda e de Edgard RoquettePinto, demonstrando que tal campo de conhecimento não permaneceu unilateralmente conformador da reflexão sobre o tipo nacional, sendo também realimentado e sustentado pela forma com que esses antropólogos, enquanto intelectuais, imprimiam suas leituras sobre tais tipos. Assim, as ambiguidades presentes em seu pensamento são também fruto de um ir e vir entre a produção da ciência e as demandas frente aos desafios de pensar a nação. De forma complementar ao capítulo de Santos, em "Crânios, corpos e medidas", Guilherme José da Silva e Sá, Ricardo Ventura Santos, Claudia Rodrigues-Carvalho e Elizabeth Christina da Silva analisam a constituição do acervo de instrumentos craniométricos e antropométricos do Museu Nacional como objeto de leitura não só da história de uma disciplina científica, a antropologia física, mas também dos ideários sobre raça e dos debates acerca da 'constituição do povo'.

Se os determinismos raciais atravessaram de forma mais nítida os debates intelectuais durante a Primeira República, inflexões podem ser observadas a partir da década de 1930, principalmente pela obra de Gilberto Freyre, costumeiramente pensada como um dos marcos inaugurais de uma reinterpretação da raça e do discurso sobre a nação, bem como da viabilização de um mito: o da 'democracia racial'. Em capítulo intitulado "'Estoque semita' e a presença dos judeus em Casa-grande \& senzala", Marcos Chor Maio situa a perspectiva supostamente antissemita de Gilberto Freyre em sua obra, à luz das análises de Ricardo 
Benzaquen de Araújo, em Guerra e paz (1994), enfatizando o neolamarckismo como chave de compreensão entre natureza e cultura, entre determinismos e processos histórico-culturais.

Retomando as transformações que surgem nos debates mais contemporâneos, os autores Santos e Maio analisam momento crucial da discussão sobre raça no contexto mundial, a saber, as reuniões da Organização das Nações Unidas para a Educação, a Ciência e a Cultura (Unesco), no imediato pós-Segunda Guerra Mundial. A suma importância de colocar em xeque o argumento que serviu de base para a morte de milhões de pessoas e para a deflagração catastrófica do Holocausto mobilizou a entidade a formular documento que buscasse invalidar raça como conceito científico. Como demonstram os autores/organizadores do livro, os dissensos em meio à própria comunidade científica que elaborou os textos mostraram o complexo emaranhado em que se encontram os posicionamentos de biólogos e antropólogos, inseparáveis de suas crenças e valores sobre a ciência, e de sua inevitável reverberação sobre o campo da ética.

A questão da raça, reiteramos, é espinhosa, e enfrentá-la significa não sair ileso às eventuais farpas desse debate. Isso se evidencia à medida que o tema é desdobrado sobre a contemporaneidade. As fricções entre setores distintos, como os da biologia, da antropologia e da política, bem como suas interpenetrações, tornam-se então agressivas, em vista das implicações diretas que as enunciações de cada grupo formam sobre o curso da vida de mulheres e homens.

É nesse ponto que o livro ganha acento próprio em relação à organização anterior, Raça, ciência e sociedade. Ao perscrutar a questão das identidades e seu modo de se apropriar contemporaneamente da divulgação científica da era genômica, Raça como questão traz à tona as indagações sobre os desafios políticos do tempo presente, em especial sobre as várias maneiras como têm sido interpretadas as políticas afirmativas. Nos capítulos seguintes, são apresentadas as tensões que emergem nos múltiplos entrecruzamentos dos estudos sobre a 'variabilidade biológico-genômica' das populações com as formações identitárias e com políticas que visam à redução das desigualdades socioeconômicas, tendo por base a cor. Essas tensões podem ser observadas no capítulo "Retrato molecular no Brasil", que trata da recepção da pesquisa do geneticista Sérgio Pena por grupos em posições políticas opostas: um representante do movimento negro e um de extrema direita. Ambos rechaçaram os artigos de Pena e de coautores, ao julgar 'político-ideológicas' as conclusões dos cientistas sobre a variação genética brasileira, feita a partir de amostragens populacionais de um município do estado de Minas Gerais. O que pesa, na avaliação de Ventura e Maio, sobre um paralelo entre ambas as perspectivas (não obstante suas enormes diferenças) seria a reivindicação de perspectivas racialistas no reconhecimento de grupos humanos, um de cunho igualitário (movimento negro) e outro hierárquico (neonazistas).

No oitavo capítulo, os organizadores, junto com Maria Cátira Bortolini, repensam o desenvolvimento tecnológico de identificação do DNA e suas consequências. Os autores notam 'aparente contradição' na forma como empresas e grupos se apropriaram da tecnologia para fornecer dados genéticos a indivíduos, em nova construção de identidades que endossaria os estereótipos raciais negados justamente pela genética. Aí talvez nos caiba perguntar se, de fato, seria algo paradoxal ou contraditório o que o próprio livro toma 
como premissa: as tramas entre ciência e sociedade recriam novas formas de (des)entendimento da raça, sobretudo no campo nada autoevidente das buscas identitárias.

A questão da identidade em seu entrecruzamento com a ciência ressurge na análise de Verlan Valle Gaspar Neto e Ricardo Ventura dos Santos, sobre a recepção que imprensa e segmentos da sociedade oferecem aos estudos paleoantropológicos sobre Luzia. O 'nascimento científico' do crânio em que foram ressaltadas concomitantemente sua antiguidade e sua aproximação morfológica de outros materiais da Melanésia, Austrália e África não deixou de servir a novos usos do passado pela sociedade. Muito curiosas são as representações da suposta figura que teria encarnado Luzia, ilustrada em alguns materiais jornalísticos e didáticos, mostram os autores, como uma caricatural 'africana'. De todo modo, essas representações do crânio encontrado em Lagoa Santa ajudariam a, mais uma vez, colocar a raça em evidência no imaginário referente a uma pré-história nacionalizada como 'brasileira'.

Os capítulos 10 e 11, escritos pelos organizadores e por Marcos Chor Maio e Simone Monteiro, respectivamente, lidam com as vias de mão dupla entre as novas identidades étnico-raciais e as políticas públicas em educação e saúde. No contexto de criação da Secretaria de Promoção da Igualdade Racial, as indagações dos autores voltam-se para os novos desafios gerados pela adoção do sistema de cotas raciais, que teriam também implicações nas maneiras de conceber a nação. Tratam, assim, da implementação pela Universidade de Brasília, em 2004, de inscrição diferenciada ao vestibular para aqueles que pretendiam concorrer a vagas de cotistas, utilizando instrumentos como fotografias para a classificação desses candidatos, o que mais uma vez reificaria velhas formas de apreensão da raça. No caso das políticas de saúde, atenta-se sobre o percurso da setorialização nesse campo por meio da eleição de programas específicos voltados para a saúde da população negra. Essas mudanças, iniciadas na última década do século XX, refletem debates vindos de diferentes fóruns, tanto nacionais como internacionais, mostrando a guinada para o problema das representações coletivas no tempo presente.

Um dos maiores méritos do livro é provavelmente o de estabelecer o constante questionamento sobre palavra do nosso vocabulário tão pisada e repisada no cotidiano e que acaba por permanecer de difícil determinação, exigindo, antes de qualquer tomada de posicionamento rígido, cautelosa reflexão.

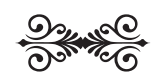

